\title{
TTR
}

Traduction, terminologie, re?daction

\section{Translation, Semiotics and Ideology}

\section{Susan Petrilli}

Volume 5, numéro 1, 1er semestre 1992

La pédagogie de la traduction : questions actuelles (1) et Miscellanées traductologiques

URI : https://id.erudit.org/iderudit/037115ar

DOI : https://doi.org/10.7202/037115ar

Aller au sommaire du numéro

Éditeur(s)

Association canadienne de traductologie

ISSN

0835-8443 (imprimé)

1708-2188 (numérique)

Découvrir la revue

Citer cet article

Petrilli, S. (1992). Translation, Semiotics and Ideology. TTR, 5(1), 233-264.

https://doi.org/10.7202/037115ar d'utilisation que vous pouvez consulter en ligne.

https://apropos.erudit.org/fr/usagers/politique-dutilisation/ 


\section{Translation, Semiotics and Ideology}

\section{Susan Petrilli}

\section{Semiosis as translation}

Victoria Welby (1837-1912) describes man's capacity for signification in terms of "translative thinking," an automatic process "in which everything suggests or reminds us of something else" (Welby, 1983 [1903], p. 34). Translated into semiotic terms we could say that translative thinking is a semiosic process in which something stands for something else, in which different sign systems are related, in which one sign is more fully developed, enriched, criticized, put at a distance, placed between inverted commas, parodied or simply imitated, and, in any case, interpreted in terms of another sign. Translation is a method of investigation and discovery, says Welby (1983, p. 150), of verification and acquisition of knowledge and development of critical consciousness:

As language involves both unity and distinction (the one actually and the other implicitly), language must itself be recognised as a means of discovering contrasts together with the links which constitute these elements of unity, or at least completely exclude the idea of final disparateness [...] For a thing is significant, both in the lower and in the higher sense, in proportion as it is expressible through bare sign or pictorial symbol or representative action. In the higher sense (that of vital or moral or rational import) it is significant in proportion as it is capable of expressing itself in, or being translated into, more and more phases of thought or branches of science. The more varied and rich our employment of signs [...], the greater 
our power of inter-relating, inter-translating, various phases of thought, and thus of coming closer and closer to the nature of things in the sense of starting-points for the acquisition of fresh knowledge, new truth (italics my own).

We could develop such intuitions in the light of more recent results of studies in language theory and the science of signs generally and state that semiosis, that is, the situation in which something functions as a sign, cannot subsist without translation for semiosis is itself a translation-interpretation process. The role of translation is fundamental in the very constitution of the sign, both verbal and nonverbal, in the very determination of its meaning. As observed by Augusto Ponzio (1981) in a paper entitled "Polisemia e traduzione," the intimate connection between signs and translation emerges when we set the category of replaceability as a necessary condition of signness, when the sign is considered not only as something that replaces something else, but that may also in its turn be replaced by something else. Consequently, meaning is defined as a class of verbal and nonverbal sign materials in which these materials may replace each other reciprocally, in which, that is, an interpretant sign may act as a possible alternative to a previous less developed interpreted sign. In other words, as insistently stated by Charles Sanders Peirce (1839-1914), a sign subsists thanks to another sign acting as its interpretant, so that its meaning is its translation into some further sign. It subsists only in relations of reciprocal translation and substitution among signs with respect to which the original sign is never given autonomously and antecedently.

In the citation above Welby explicitly states that "while language itself is a symbolic system its method is mainly pictorial" (ibid., p. 38). Through recourse to Peirce's most basic tripartition of signness into symbolicity or conventionality, indexicality and iconicity (cf. Peirce, 1931-1958, 2.247-2.249; also Letter of Oct. 12, 1904 from Peirce to Welby, in Hardwick 1977, pp. 22-25), we could "translate" or "reword" this sentence as follows: "if verbal language itself is a conventional system its method is mainly iconic." In other words full recognition is given to the role of iconicity in the development and multiplication of signifying processes, to the iconic relation of hypothetical similarity in verbal language. 
Reference here to the Tractatus Logico-Philosophicus by Ludwig Wittgenstein (1889-1951) in the interpretation of Ponzio (cf. 1991, pp. 185-201) is instructive. Wittgenstein distinguishes between names and propositions: the relation between names or "simple signs" used in the proposition, Welby's "bare sign" as reported above, and their objects or meanings, is of the conventional type. In fact, being arbitrary, the rule or code relating the sign to the object to which it refers cannot be discovered simply by guessing: sign arbitrariness is a category proposed by Ferdinand de Saussure (1857-1913) in his book of 1916 to characterize certain types of signs - verbal signs, or words taken singly, and nonverbal signals. On the other hand, the relation between whole propositions or "propositional signs," Welby's "pictorial symbol" and "representative action," and what they signify, their interpretant, is a relation of similarity, that is, of the iconic type. Wittgenstein's "proposition," like Welby's "pictorial symbol" and "representative action," are complete signifying units with a high potential for semiotic resonance.

In his Philosophical Investigations Wittgenstein develops the role of situational context in the completion of the proposition's representative and therefore signifying function. Thus contextualized, the "proposition" is transformed into "utterance" as understood especially by Mikhail Bakhtin (1895-1975), who made a thorough analysis of this particular category with reference to the Russian word vyskazyvanie (cf. Bakhtin 1986; Bakhtin-Volosinov 1973; 1987). The utterance, when dominated by an iconic relation between the interpretant sign and the interpreted sign is, as Bakhtin demonstrated, a dialogic relation of "answering comprehension" with a lesser or higher degree of alterity. Accordingly it is endowed with a varying capacity for criticism, cognitive innovation, and creativity.

In relation to Wittgenstein, Ponzio (1991, pp. 198-199) makes the following observation:

Even though propositions are also no doubt conventional-symbolic, they are based fundamentally upon the relation of representation, that is, upon the iconic relation and, similarly to Peirce's "diagrams," this relation is of the 
proportional or structural type. Consequently, in Wittgenstein's view, the proposition is a logical picture.

To know a proposition, says Wittgenstein, means to know the situation it represents; furthermore, comprehension of a proposition does not require that its sense be explained, for "a proposition shows its sense" (4.022). Hence while "the meanings of simple signs (words) must be explained", "with propositions [...] we make ourselves understood" (4.026). The importance of Wittgenstein's picture theory for a better understanding of the processes of language production and, by extension, of signification generally, is commented by the same Ponzio (ibid., p. 199) in a way that we could easily apply to Welby:

[...] as a logical picture, representation tells of the mechanism that produces propositions and explains how language, through propositional signs, is able to escape the pure and simple convention of names, which would render [language] altogether repetitive. The question invests the mechanism of the production and development of thought given that "a logical picture of the facts is the thought" and that "a thought is a proposition with a sense" [Ponzio is here referring to propositions 3 and 4 of the Tractatus].

For both Welby and Wittgenstein of the Tractatus language analysis must not merely limit itself to the surface description of signifying phenomena, of language and thought, but must account for the production processes of such phenomena. At this point we shall simply signal a connection with the reflections of Ferruccio Rossi-Landi (1921-1985) on the specific notions of common speech, linguistic work and, in a more mature phase of his theoretical elaborations, social reproduction (cf., for example, Rossi-Landi 1961; 1968; 1985; see below).

The work of Welby, Wittgenstein, Bakhtin and above all Peirce helps account for the more complex levels of signification, expression and communication - and not as they are reduced, that is, to the mere function of information and message exchange. Each of these scholars calls our attention to the importance in communication of iconic representation and alterity, of establishing relations among signs even 
beyond systemic restrictions. Such an orientation also helps to highlight the dialectic nature of ongoing interpretative-translative interactive processes between "unity and disparateness", as Welby says in the citation above, between the centripetal forces and the centrifugal forces operating in language, as Bakhtin would say (1981, p. 272), between centralization and decentralization, between monolingualism and plurilingualism, monologism and polylogism, identity and alterity. Thanks to such dialectics, knowledge and truth are never given once and for all, but rather are open to continual investigation and modification in a process of constant renewal and adaptation to ever new communicative requirements, at the level of simple everyday exchange as well.

We shall now refer to Roman Jakobson's (1896-1982) analysis of translation and connect it with Peirce's subdivision of signs into symbols, indexes and icons. Any one given sign (identifiable as such only by abstracting from real semiosic processes for the sake of analysis) is the product of dialectic interaction among conventionality, indexicality and iconicity even if one of these aspects prevails in a given sign situation. By considering this Peircean tripartition in conjunction with the analysis of translative-interpretative processes as proposed by Jakobson, we obtain a more adequate specification of the relation between translation and signs and a more precise, and yet broader, characterization of the interpretative-translative processes constituting and proliferating in our semiosphere.

In his paper "On Linguistic Aspects of Translation", Jakobson (1971, pp. 260-266) distinguishes three possibilities of translating or of interpreting verbal signs: 1) intralingual translation or rewording which refers to the interpretation of verbal signs by means of other signs of the same language; 2) interlingual translation or translation proper which refers to the interpretation of verbal signs by means of some other language; 3 ) intersemiotic translation or transmutation which refers to the interpretation of verbal signs by means of signs of nonverbal sign systems. Each of these translative-interpretative modalities presents a relative predominance of conventionality, indexicality or iconicity, a relative predominance in the relation between a sign and its interpretant of the symbol, index or icon. Furthermore, these three types of translation as identified by Jakobson are always 
interrelated, are more or less co-existent with a relative predominance of one or the other. For example, in interlingual translation, for a full understanding of the sense of the object of translation and its adequate rendition in the "target" language, it will also be necessary to continually resort to intralingual translation in each of the two languages in question.

When conventionality predominates, the relation between a sign and its object (or referent) is established by a code. This occurs in verbal language, and is the kind of relation alluded to by Welby when she says that " [verbal] language [..] is a symbolic system." We know that reference to the code in the decodification of linguistic elements is an inevitable aspect of translative processes, especially in the initial phase of text decipherment. At this level distancing between interpretant signs and interpreted signs is minimal, the mere activity of recognition and identification being of first importance.

Moreover, relations of an obligatory nature also intervene between signs and their interpretants. Insofar as it is compulsory, this relation takes on the aspect of indexicality as intended by Peirce. To mechanical necessity a bilingual dictionary adds the relation of contiguity - proper to the index, says Peirce, jointly with causality between the sign and its interpretant, when it places the vocable and its equivalent(s) in the target language alongside each other. Therefore, interlingual translative processes present indexicality in addition to mere conventionality. It is in this perspective that we may read Wittgenstein's observation on translation from the Tractatus $(1961,4.025)$ :

When translating one language into another, we do not proceed by translating each proposition of the one into a proposition of the other, but merely by translating the constituents of propositions.

Indexicality refers to the compulsory nature of the relation between a sign and its object, a relation regulated by the dynamics of cause and effect, of spatio-temporal necessary contiguity, pre- existent to interpretation. Where indexicality predominates translation-interpretation processes simply serve to evidence 
correspondences where they already exist. The degree of creative work involved is minimal.

Bakhtin, who envisages communication and social intercourse in terms of dialectic and dialogic interaction between identity and alterity, introduces another two categories important in his analysis of verbal language though extensible to other sign systems as well: "theme" (smysl) and "meaning" (znacenie), or if we prefer, "actual sense" and "abstract sense" (cf. Bakhtin-Volosinov, 1973, p. 106). The second term in these pairs covers all that which is identical, reproducible and immediately recognizable each time the utterance is repeated - it concerns the meaning of linguistic elements, e.g. phonemes and monemes, forming the utterance. "Meaning" thus intended corresponds to signality rather than to signness, to the "interpretant of identification," rather than to the "interpretant of answering comprehension," to "plain meaning," rather than to plurivocal meaning, to translation processes (and phases) where the degree of dialogicality and distance regulating the connection between interpretant sign and interpreted sign is minimal. "Theme," instead, refers to all that which is original and unreproducible in an utterance, to its overall sense, signifying import and evaluative orientation as such aspects emerge in a given instance of communicative interaction. This category accounts for communication and signifying processes in terms of answering comprehension, dialectic-dialogic response, multiaccentuality - it concerns translation-interpretation processes capable of qualitative jumps in knowledge and perception, of amplifying the semantic polyvalency of discourse, of opening new ideological horizons. As says Bakhtin (ibid., p. 100):

Theme is a complex, dynamic system of signs that attempts to be adequate to a given instance of generative process. There is reaction by the consciousness in its generative process to the generative process of existence. Meaning is the technical apparatus for the implementation of theme.

In interlingual translation, iconicity, or the iconic relation between a sign and its interpretant, is present as well. Indeed, this relation is determinant for without it the sense of discourse could not be rendered, and well might we state that if translation processes remain 
at the level of conventionality and indexicality, the translator ends in failure. When in relation to translative-interpretative processes Welby states so simply and clearly that the method of language is pictorial, she is evidencing a component of verbal signs irreducible to indexicality or to conventionality. The translator must necessarily deal with this component by moving beyond the conventions and obligations of the dictionary and entering the live dialogue among national languages, among languages internal to a given national language, among verbal signs and nonverbal signs. The presence of iconicity in interaction between interpretant signs and interpreted signs in translative processes involves dialogism and alterity to a smaller or greater degree.

Iconicity implies that the relation between a sign and its object is not wholly established by rules, by a code, as in the case of symbols, does not preexist with respect to the code, as in the case of indexes, but rather is invented freely and creatively by the interpretant. This is something that the interpreter, in our case the translator, must inevitably keep account of given the task of having to render the original interpretant with the interpretant of another language. In the case of icons, then, the relation between a sign and its object is neither conventional, nor necessary and contiguous, but hypothetical - it corresponds to Bakhtin's "theme," or "actual sense."

Where the relation between a sign and its object, between varying different types of signs, is regulated by the iconic relation of similarity, affinity and attraction, as Peirce would say (cf. 1956), ongoing interpretative-translative processes forming the signifying and cognitive universe are founded upon dialogism, alterity, polyphony, polylogism and plurilingualism - all essential properties of language which render such things as critical awareness, experimentation, innovation, and creativity possible.

What has been said $d$ propos interlingual translation is also valid for intralingual and intersemiotic translation. It has also been observed that interlingual translation implies the other two types of translation. Hence the translative process always involves a process of interaction between the three types of sign- interpretant relation as identified by Peirce and the three modalities of translation as identified by Jakobson. 
Once the fact that meanings subsist and flourish in translation processes has been recognized, the importance of the relation between identity and alterity and of plurilingualism generally, both internal and external to a single language, emerges more clearly. In the framework of the semiotics of interpretation, and as especially the studies of Bakhtin have revealed, it has now become obvious that communication is a primary function of human language when it is viewed not in its potential for the transmission of messages, but when first importance is attributed to such properties as the capacity for: imprecision, vagueness, ambiguity, inscrutability, concealment, reticence, the unspoken, allusion, implication, simulation, imitation, pretence, semantic pliancy, polysemy, polylogism, plurilingualism, alterity - all of which determine the very possibility of communicative interaction.

Concrete live speech is possible thanks to continual translation operations on the side of both production and interpretation in the passage from one code (linked to class, linguistic register, idiolect, genre, etc.) to another, from one language to another, from one communicative context to another. For successful communication-translation, "active comprehension" is necessary. This involves speakers' abilities to adapt and reformulate their own language to suit their interlocutors, to reflect metalinguistically upon their own language in the effort to specify what they mean through recourse to interpretants from the language of others, to reflect metalinguistically upon the language of others in order to specify their meanings in terms of interpretants from their own language. "Active or answering comprehension" concerns the theme or actual sense of an utterance. It is achieved thanks to dialogic relations among different languages and codes which permit operations of rewording, transposition, and transmutation in the deferral among interpretants as they substitute for each other without, however, ever perfectly coinciding.

Far from being a compact, unitary and monolithic phenomenon, human language may be described as a live signifying process, a process in constant renewal generating different idioms, different discourses, different logics and points of view thanks to a predominant tendency towards decentralization and otherness. Plurilingualism and polylogism, both internal and external to a single language, derive from the possibility verified in human language of distancing, of expressing 
points of views that are other, different worldviews: indeed human language develops in its plurality and multiplicity as a function of this very possibility.

Remembering the words of George Steiner (1975), we may add that language thus intended is the main instrument that man has at his disposal for refusal of the world as it is, that is, as a static and coherent block. Even though each language presents, to a greater or lesser degree, its own particular reading of reality, it is thanks to its inherent alterity and to the possibility of translating, of moving across different languages and cultures, that man discovers the almost disconcerting pleasure of freedom. From this point of view, as observed by Thomas A. Sebeok (1981), language not only concerns the real world, but also infinite possible worlds, and this gives man that particular freedom which, to use the title of Sebeok's book, may be called "the play of musement."

\section{Translatability and untranslatability}

\section{1. Translation and the theory of linguistic relativity}

The following quotation is taken from a book of 1973 by Rossi- Landi dedicated to the problem of Ideologies of Linguistic Relativity as stated in the title (with particular reference to the work of Benjamin Lee Whorf and Edward Sapir):

Language (le langage) is the dialectical sum of a language (une langue) and common speech. [...] The generative and self-extensive power of a language is therefore not a property inherent in it, but comes from the fact that we use it when we speak, and in this use of it, we bend it to our purposes. Language-in-general is everything that is used for linguistic production. In this production, as in any other, we can distinguish (1) a constant capital, which is the language [langue], (made up of linguistic materials, instruments, and 'money'), (2) the linguistic working processes constituting common speech, and (3) a variable capital constituted by the linguistic workers, that is the speakers. The generative and self-extensive power usually attributed to the language as such 
[langue] is thus a characteristic of language-in-general, more or less as the growth of constant capital is in reality a characteristic of production viewed as a whole. But in linguistic production, as in material production, it can happen, and indeed it usually does, that the constant capital takes on a sort of apparently autonomous, monstruous life of its own, subordinating to itself those expenders of linguistic labour power, without whom it could never have formed nor could it continue to exist (Rossi-Landi, 1973, p. 63).

As implicitly indicated by his recognition of "the generative and self-extensive power" of a language, and his criticism of extreme forms of linguistic relativity which view languages as closed, separate and self-sufficient universes unable to communicate among themselves, Rossi-Landi supports the thesis of interlingual translatability. As distant as languages may be from a cultural point of view, as in the case of languages deriving from different families such as the the Amerindian and European, translation is always possible. "After all we do succeed in translating," says Rossi-Landi (ibid., p. 53) and even where codes, expressions and propositions cannot remain identical or at least similar in the transferral from one language to another, it will still be possible to reconstruct one language in terms of the other either by describing the first metalinguistically or by expanding the second. "An ability to speak a given language implies an ability to talk about this language," says Jakobson (1971, p. 262) who calls our attention to the complementarity of the object level and the metalinguistic level of language. In fact, had linguistic universes been mentally incommensurable, says Rossi-Landi, it would never have been possible for Whorf or anyone else to describe linguistic universes distant from our own, in English, while at the same time theorizing on the impossibility of such operations. As says Rossi-Landi (1973, p. 54):

Every culture is capable of being informed IN its language as to the limitations of its own experiences, including those OF the language itself; and it is also possible to complete any language and thus any culture with certain aims in view, abandoning the level of mere metalinguistic description of what takes place in another language to move to that of the 
re-elaboration, or, at least, the correction and enlargement of the very code which is being used.

This position finds support in the work, for example, of the same Jakobson who, echoing Peirce, states that "any sign is translatable into a sign in which it appears to us more fully developed and precise." And continuing:

All cognitive experience and its classification is conveyable in any existing language. Whenever there is a deficiency, terminology can be qualified and amplified by loanwords or loan-translations, by neologisms or semantic shifts and, finally, by circumlocutions (Jakobson 1971, p. 263).

To support the thesis of translatability does not imply that languages equal each other, that their underlying structures are identical or that their vocables may be superimposed. The thesis of translatability, of communicability among languages does not imply adherence to linguistic universalism, to the belief that the great plurality of different languages may be reconducted to a single language, to an Ursprache, to universal linguistic structures, or to innate mental structures and, ultimately, to a monologic view of reality. Languages always maintain a margin of alterity and distancing with respect to each other, not only in the more obvious case of the different natural languages, but also in situations of internal plurilingualism. Indeed, as stated earlier, the capacity for differences and distances, for variation in point of view and linguistic register is a necessary requirement and the very condition of communication. In the words of Ponzio (1981, p. 38):

Languages are always endowed with their own specificity, with reciprocal alterity however strong their cultural proximity may be, and in any case, indeed, I would say, precisely because of this it is possible to translate a text from one language to another.

It is thanks to alterity that we are able to operate at a metalinguistic level not only within one and the same language, but across different languages, different sign systems. The target language offers the possibility of greater metalinguistic distancing with respect to 
the source language and, therefore, it makes further materials available for the development of the chain of interpretants. Indeed, the metalinguistic function compensates for the situation of non identification among the linguistic universes of different languages which at the same time, however, in spite of their reciprocal alterity, as observed previously, are not incommensurable.

From the dynamics between identity and alterity derives the possibility of realizing different forms of reported discourse - direct, indirect and free indirect - and their variants (cf. Bakhtin-Volosinov, 1973). The different forms of reported discourse correspond to as many different ways of relating reporting discourse to reported discourse, of perceiving, reformulating, representing the discourse of others, to the different ways of translating the discourse of others into one's own discourse. Furthermore, as demonstrated particularly by Bakhtin (cf. $1984 a ; 1984 b$ ), the dynamics between identity and alterity, between the various forms of reported discourse, is a determining factor in the very production and proliferation of the different literary genres. In relation to poetic language Jakobson $(1971$, p. 266) states that "poetry by definition is untranslatable," indeed,

Only creative transposition is possible: either intralingual transposition - from one poetic shape into another, or interlingual transposition - from one language into another, or finally intersemiotic transposition - from one system of signs into another, e.g., from verbal art into music, dance, cinema, or painting.

All the same, in spite of what would seem to be described as a limitation, by referring to Bakhtin we could state that thanks to the action of alterity and dialogism in language, poetic language included, this very transposition is in any case and always in some way possible.

Returning to the passage quoted above from Rossi-Landi, a language's potential for expressing and communicating anything from some other language, far from deriving from some arcane quality inherent in a superindividual reality called langue, is the result of a dialectic interaction between langue and what Rossi-Landi calls common speech - the interpersonal and collective set of techniques underlying 
expression and communication and common to all individual speakers: in other words, "the generative and self-extensive power of a language" does not coincide with the langue but is connected with language-in-general.

Rossi-Landi develops his thoughts upon language and signifying processes generally in a Marxian framework. Thanks to this approach he comes up with such notions as "linguistic production," "reproductive capacities inherent in all languages," "linguistic work," "linguistic use," "linguistic instruments," "linguistic materials," and "linguistic workers," underlining the dialectic-dialogic interrelation among all these components for the successful realization of communication. The implication is that human language is first of all a social reality, which means that it is a live, mobile and dynamic reality always in the making through ongoing linguistic production and reproduction processes - the result of interaction between langue and common speech. Rather than just view language as something given, clearly defined and definitive then, Rossi-Landi too (see also 1968; and 1973), like Welby, Peirce, Bakhtin and Wittgenstein before him, contributes, from yet a different angle, to focusing on the actual processes of linguistic production, upon the processes that make expression and communication possible.

Supporters of extreme forms of linguistic relativity and therefore of the thesis of interlingual untranslatability, says Rossi-Landi, confuse langue with langage, reductively putting the former in the place of the latter while separating it from speech, so that the global process of linguistic production is replaced by a part - constant linguistic capital. Remembering that difficulties in interlingual translation concern langue and not speech, nor langage or linguistic production generally, to replace langage with langue means that any "new work" carried out by speech in that very same langue (constant capital), that any modifications eventually effected upon the constant capital (langue), are ignored.

Another significant misunderstanding underlying the thesis of interlinguistic untranslatability consists in confusing the use of products, of already existing linguistic capital, with production, in attributing to the system of products properties which in fact belong uniquely to 
work. In other words, individual speakers use linguistic products which they partially reproduce. Such products are the result of historico-social production processes and never of individual labour viewed in isolation. Mental processes do not exist separately from linguistic work but coincide with it. Consequently linguistic use does not necessarily condition thought in a one way process, but the two elements intermingle in the process of linguistic reproduction, in its turn part of a global dialectically interactive situation of economic, social and cultural relations.

This description captures the reality of language in all its dialectic dynamism which as such is endowed with the potential capacity of looking at one linguistic universe with the eyes of another, or of reproducing or generating one linguistic universe within the ever flexible boundaries of another - "plasticity" or "elasticity" in fact is a characteristic of language theorized by Rossi-Landi, similarly to Welby, as a condition of the very continuity of its existence and development. Indeed, for both authors, the plasticity and signifying pliancy of language is a fundamental quality in maintaining its adequacy as a means for the expression, communication and eventual acquisition of new knowledge, in adapting to ever new linguistic uses and purposes, to ever new communicative contexts, thus constituting a necessary condition for the successful realization of interpersonal communication.

\subsection{Translation, semantic gaps and sign residues}

Even in the case of closely related languages, translation is at times difficult, inadequate or practically impossible (on a scale of difficulties we could place a scientific treatise at one extreme and poetry at the other). Obstacles to communication among different universes of discourse, among different languages, may be present systematically at various levels. The following are some brief examples, proposed by Rossi-Landi, of relative untranslatability resulting from a confrontation at various levels between the superficial signifying structure of the two natural languages, English and Italian:

1) vocabulary, where difficulties arise because of the greater or lesser availability of corresponding terminology. Italian words generally carry more meanings than the English simply because they are 
less numerous. This phenomenon, which has historical causes and is open to various interpretations, has been designated by the term polysemantism. An immediate example is the Italian "vitello" which is rendered in English by either "calf" or "veal" depending on whether we are speaking of a live animal or a serving of meat;

2) syntax, where problems of untranslatability would seem to be more serious and concern not only syntactic correspondences at a formal codified level, but also the signifying capacity that words may assume in various contexts. The proposition expressed in Italian with either "Giovanni disse chiaramente" and "chiaramente disse Giovanni" if translated according to the rules as "John said clearly," loses a shade of meaning in English;

3) concept families, where noncorrespondence between the two languages may give rise to such serious cases of untranslatability that not even context or paraphrase can offer an adequate solution. The distinction in English between "sense" and "non-sense" and "meaningful" and "meaningless" do not find their exact Italian equivalents in "senso" and "non-senso", or in "significante" and "non significante". In relation to this particular semantic field it is worth noting that Frege's distinction between Sinn and Bedeutung has been rendered in English (by no less an authority than Russell) by meaning and denotation while in Italian, however, it is rendered by senso and significato on translating from the German, and by significato and denotazione on translating from the English.

Despite the existence of areas of untranslatability, and even if stylistic elegance must at times be sacrificed, it is generally agreed, we have observed, that the universes of discourse of even distant languages more or less cover each other. The extent of such reciprocal coverage, which does not exclude areas of untranslatability in one language, or introduction of new signifying material in another, may be verified, says Rossi-Landi, in terms of communication as it is effectively realized across languages (though for some concepts it is more a question of expressibility in two or more languages than of communication among languages), and of the status of eventual "residues". 
If we consider the concept of "sign residue" in relation to translation, viewed in terms of the connection between signs and interpretants, we soon become aware of how useful this concept may be in understanding the non-exhaustive and never definitive character of the work of translation, just as the work of interpretation is never exhaustive or definitive. In fact, the sign residue is the uninterpreted sign residue of the interpreted sign in relation to a given interpretant sign and constitutes that part of semiotic materiality which enables a sign to be translated into any number of interpretative itineraries without ever necessarily losing its initial sense because of this. The uninterpreted sign residue constitutes the very condition of the sign's ambiguity, polysemy and otherness, which determines the fact that even if produced by an original signifying intention, once this sign is freed from its source it is open to infinite possible interpretative-translative developments (on these aspects see also Ponzio, 1990b, pp. 15-74; see also Petrilli, 1990b, pp. 373-380).

Reciprocal coverage among different languages, which, as should now be cbvious, never attains perfect correspondence, may be measured from the viewpoint of the material forming languages historically, that is, by confronting the level of development of phonological and morphological complexes, of verbal material, as well as by confronting the level of development of civilization in its various aspects, of socio-cultural material, including the nonlinguistic and the ideological, to which languages belong and of which they are the expression. Such an analysis cannot simply be dealt with satisfactorily in terms of a classification of translation difficulties manifest at the level of signifying structure.

\subsection{Translation and common speech}

On the basis of what kind of signifying material, asks Rossi- Landi, is a philosopher able to uphold, at one and the same time, both the individuality of his work in its historical and cultural determinations, as well as its universal relevance to mankind? For a more profound understanding of such questions which goes hand in hand with an understanding of the underlying processes involved in situations of intralingual, interlingual, and intersemiotic communication, the proposal is that we proceed by identifying a level of reference common to all 
languages, that we inquire into a sort of a priori of language - in the Kantian sense - , a pre- linguistic level intended as all the operations that constitute and make speaking and communication possible: Rossi-Landi's "common speech." Such common territory, which enables the passage from one universe of discourse to another and communication among and of the various natural and technical languages, can only be identified by focussing on the processes that are constantly at the basis of the empirical procedures carried out by whoever is producing language - whether translating, teaching or learning it. This is research into the pre-linguistic level of language, into language in its connection with thought (cf. Rossi-Landi, 1961, 240ff).

Common speech refers to all the common operations necessary in speech for successful communication among human beings. It refers to the basic similarities in biological and social structure uniting all human communities beyond historical and geographical differences. As the set of social techniques necessarily used by all speakers, common speech underlies all natural, special or technical languages. In the face of smaller or greater areas of untranslatability, this common set of techniques makes translation processes in any case possible. And as Ponzio (1990c, p. 125) specifies in one of his numerous studies on Rossi-Landi:

The notion of common speech does not oppose that of plurilingualism [...] On the contrary, precisely because common speech is nothing more than a similarity of functions fulfilled by the various languages in satisfying needs of expression and communication, it can explain and justify the difference, variety, and multiplicity of the different languages as being due to the variety in expedients, solutions and resources that each language offers [...] for the satisfaction of the basically similar social needs of expression and communication.

Common speech does not reconduct the multiplicity of languages to a mythical original language, to an Ursprache, to the universal linguistic structures of Logos or to some biological law governing all human languages. This is further explained by Rossi-Landi in his important 1968 book, Language as Work and Trade, and in subsequent writings where, in the perspective of historical 
materialism, the notion of common speech is reformulated, as mentioned above, in terms of work, that is linguistic work (and later of social production):

The similarity of the functions fulfilled by the various languages is derived from the fact that in the process of language development the general forms of social formation, that is, the basic work and production relationships that separate any human society from any pre-human (only) animal society, are necessarily represented (Rossi-Landi, 1968; Eng. trans. 1983, p. 41).

The theory of common speech seeks to explain linguistic use and not simply describe it as did the Oxonian analytical philosophers (in LWT Rossi-Landi criticizes Wittgenstein's notion of use as developed in Philosophical Investigations, maintaining that the linguistic unit is analysed as something that is already given without inquiring into the social processes that produce it, so that its social character is left aside). Rather than describe linguistic use as it is realized in a given natural language, Rossi-Landi, with his notion of common speech, aimed at identifying the general conditions of language-thought at the basis of linguistic use and valid beyond the limits of any one given natural language. By no means an immediate description of real processes, common speech is a theoretical construction, a model proposing a method with interpretative functions, a hypothesis applicable to different languages (Rossi-Landi, 1961, p. 26). It refers to a set of techniques forming the necessary conditions for the happy realization of expression and communication, techniques which in their repeatability and constancy are common to all human beings, in Ponzio's words (1990c, p. 132), it concerns

[...] fundamental categories, structures, signantia and signata of various description because the human situation is what it is, biologically and socially, all over the earth in spite of relevant local variations.

As such common speech is not bound to national-cultural spheres but is an international phenomenon, it is not the theoretical expression of the historical processes of linguistic and ideological 
unification and centralization, of the "centripetal forces" in language says Bakhtin, it is not connected with the notion of langue. As Rossi-Landi maintains (1961, p. 169) in his critique of the dichotomy between linguistic system and individual speaking, between langue and parole, between that which is permanent in language and innovation, between inventum and inventio, the notion of common speech, intended as the set of constant and reproducible characteristics of language, as language-in-general-as-human-work, cannot be reductively attributed to just one of the two poles forming such dichotomies but involves them both (for a detailed analysis and further development of Rossi-Landi's theoretical stances in its various aspects, see in particular Ponzio's monograph of 1988 Rossi-Landi e la filosofia del linguaggio).

\section{Translation, alterity and ideology}

The verbal sign is an ideological sign par excellence, says Bakhtin. As an ideological phenomenon it refracts historico-social reality. The verbal sign has an ideological function, an ideological materiality. It refracts ideologically the social reality in which it is produced and used. Insofar as it is ideological, the verbal sign may be characterized as a historico-social event.

Though nonverbal signs contribute towards shaping reality, the modelling influence of verbal signs is far greater. Reality as we experience it is organized verbally - a conviction at the basis of extreme forms of linguistic relativity. Supporters of this theory maintain that the structure of a given language wholly determines a language user's thoughts and worldview as well as his nonverbal behaviour, so that, echoing Wittgenstein (1953), we could say that our world is the language we speak. For his part, by contrast with the idealism of linguistic relativity, with opposing neopositivist stances and the conception of language, thought and reality as separate though variously interacting entities, Rossi-Landi stresses the dialectic interaction between thought, language and the economic, social and cultural context in the formation of ideologies and worldviews:

Language is immediately present, but certainly not in the form of a constant linguistic capital, capable of being isolated from everything else, and made to determine nothing less than 
thought. If we want to study the way in which thought is determined in all its developments up to the point of including spontaneous and sophisticated worldviews, we shall have to turn our attention to the sum total of economic, social and cultural conditions. We shall find that what we describe as linguistic is, if anything, a part of their phenomenology (Rossi-Landi, 1973, p. 70).

By constrast with the plurilingualism and polylogism of linguistic relativity which, while recognizing the great multiplicity of languages and worldviews, elaborates the thesis of incommunicability, incommensurability, untranslatability, of linguistic universes devoid of the possibility of relating to each other dialogically, and by contrast with the opposite extreme of reducing such multiplicity to unity, characteristic of mental innatism, biologism, linguistic universalism, Rossi-Landi highlights the dialectic-dialogic nature of the relation between language, thought and objective reality. Language shapes our worldview and, at the same time, is the product of relations among human beings, and among human beings and the "natural" environment. Language not only determines social praxis but is determined by it. However, semantic correspondences between verbal signs and objectual reality, that is, worldviews, are never direct or immediate. There is no such things as "hard dry facts," says Welby, who also stresses the signmediated nature of consciousness, language and reality, and of the relation between consciousness and reality. The objective world takes shape and may be perceived in its parts thanks to the mediation of language which in turn is the product of social practice. Awareness of reality is mediated awareness conditioned by previous, individual and collective experiences, by the specific values, ideologies and orientations of a given community, all of which find their most resonant expression in the verbal sign.

So-called "semantico-ideological pliancy" characterizes the verbal sign and is expressed in its possibility of transferring or transmuting into varying ideological fields whereby acquiring new meanings and functions. The plurivocality, ambivalence, ambiguity and semantico-ideological pliancy of the verbal sign is given in its translatability into other verbal interpretant signs belonging to different semantic classes, that have different meanings. By contrast with signals 
which in comparison with verbal signs are endowed with a low level of signness (see Bakhtin-Volosinov, 1973), verbal signs may be translated/interpreted by interpretants not only from different sign systems, as in the case of signals, but also from different classes of meaning.

Ideological multiaccentuality, projectual pluridirectionality, valuational heterogeneity, polylogism are all implied by the condition of plurilingualism, polyphony, plurivocality. Semantic alterity involves ideological alterity which concerns the valuational accentuation, practical orientation, and operative intentionality taken on by the word in concrete communicative contexts. Consequently, answering comprehension involves interpretative choices and participation not only at the semantic level but also at the ideological. It elicits a point of view that is other with respect to identity, an ideological stance, the development of a critical linguistico-ideological consciousness. All this is connected in Bakhtin with what he calls "theme" or "actual sense" which, indeed, is determined in semantico- ideological translation processes, and to what Welby intends by "significance" within the framework of her particular version of the theory of meaning, or significs.

For Welby the term "significance" indicates the maximum expression value of a sign as it is enhanced through ongoing translative-interpretative processes; the sign viewed not solely as a cognitive entity but in its axiological dimension as well, in its relation to values. The more a sign is subject to transference, transformation, transmutation, transfiguration, and above all, transvaluation, the more it is translated into the signs of different spheres of knowledge, experience, ideology, into different languages, the more its significance and ultimate value increases. Even the simple rewording - to paraphrase Jakobson, intrasemiotic translation -, of an expression in different linguistic registers, according to different communicative situations, is possible thanks to the development of a metalinguistic semantico-ideological consciousness. Ongoing translative-interpretative processes sharpen perception of even the most unsuspected links and connections, of aspects of knowledge and truth previously unknown: the more the sign is translated consciously and dialectically into different fields of thought and practical experience, the more its significance, 
import and value increases. In the framework of significs it is particularly the term "transvaluation" (cf. Welby, 1983, p. 26) that captures this aspect of the connection between translation and meaning: "transvaluation" underlines the link between translation processes in this "significal" sense and Welby's triadic subdivision of signifying processes into "sense," "meaning" and "significance" - three terms that indicate the progressive advance from the lower to the higher degrees of semantico-ideological expression value in concrete communicative interaction (cf. Welby, 1983, pp. 5-6; see also her paper "Significs", now in Welby, 1985).

Steiner, as mentioned above, speaks of freedom as it is determined in dialogic plurilingualism, in alterity, in the possibility of moving across languages and worldviews. Working in a similar direction and in the light of studies conducted on the connection between meaning and value not only by Welby or Bakhtin, but also by such different thinkers as Peirce (cf. 1956), Charles Morris (1901-1979; cf. 1964) and Emmanuel Lévinas (cf. 1989), it is worth observing that another fundamental relation to emerge is that between translation and the concept of responsibility, between translation and the freedom of unlimited, absolute responsibility. "Responsibility is what first enables one to catch sight of and conceive of value," says Lévinas (1989, p. 113). Translative-interpretative processes involve the capacity for alterity, the possibility of overcoming the limits of one's own identity, of one's own restricted responsibilities as they are reassuringly defined in professional roles, social status, political orientation, ideological convictions, etc. The capacity for alterity does not imply, therefore, a situation of indifferent, undiscriminating co-existence among a plurality of closed languages, worlds and subjects, but, on the contrary, involyes the risky responsibility of crossing over boundaries and looking at the other, of perceiving the other in a relation of dialogic participation.

The discussion concerning the translation of Theses on Feuerbach by Karl Marx (1818-1883) is worth mentioning at this stage in the light of our focus on the relation between semiotics, ideology and translation theory. Immediate reference is to the debate which took place between Adam Schaff and Lucien Seve in the French journal L'Homme et la Société in 1971 and 1972 concerning the official French translations specifically of Marx's sixth thesis on Feuerbach. This 
debate involved numerous French intellectuals (in addition to Schaff and Sève, other scholars to have figured in the discussion either directly or indirectly were Louis Althusser, Auguste Cornu, Roger Garaudy), and beyond these the international community at large with a concem for Marxist theory. Indeed, thanks also to the work of Ponzio (cf. 1975), who has collected the various interventions relevant to this debate in Italian translation in a volume entitled Marxismo e umanesimo, we are now able to extend the scope of the discussion beyond the official French translations to include the Polish, Russian, Italian and eventually the English.

Even though interest in this precise issue may seem rather restricted given its specialized nature, it is in fact of great import considering its determining role in the global interpretation of Marxist theory - many scholars believe that the Theses on Feuerbach are the key to Marx's thought even if they often give rise to different interpretations owing to their elliptical and at times metaphorical nature. Furthermore, and for what concerns us more specifically here, discussion of this particular issue is important because it serves to highlight the existence of a close relation between translation and ideology: to translate in one way rather than in another, as in the case of this text by Marx, is full of ideological implications. Consequently the solution to this particular controversy is significant at the philological, philosophical and political levels, and for the case in point it is crucial in establishing the validity of Sève's overall interpretation of Marxism and of his criticism of existentialism, structuralism, Althusser's theoretical anti- humanism, etc.

Sève considers the translation of Marx's sixth thesis by Schaff as erroneous and as the result of the latter's misinterpretation of marxism, of his reading of Marx in a humanistic-speculative key, involving consequences at the political level also. The whole debate ultimately concerned the relation between Marxism and humanism: the interpretation of thesis VI may be viewed as a reflection of the general attitude taken towards the relations between Marxism and humanism, ideology and science, scientific socialism and Marxist humanism, Marx's youthful writings and his mature works, all of which concern the meaning and value of Marxism generally (cf. Ponzio, 1975, p. 6). And as Schaff observes, though centred upon the translation and 
interpretation of just a few expressions in the Theses, the debate extends beyond "words" and can only be fully understood by looking "behind the screen," by inquiring into the history of left-wing political movements, and by relating the consequences of this debate to the "controversy on the humanistic contents of socialism, the controversy on the means of overcoming the effects and consequences of Stalinism in the Communist movement, etc." (Schaff in Ponzio, 1975. p. 114).

The immediate object of discussion and controversy concerns the correct translation of certain propositions in Theses on Feuerbach, all of which contain the German word Wesen as in the key expression das menschliche Wesen in thesis VI. Schaff contends that the recurrent translation of this expression with "the essence of man," generally consolidated by tradition, is wrong. The German word Wesen is ambiguous: it counts up to eleven distinct groups of meanings, each with numerous semantic nuances. Two of these meanings are relevant in relation to the debate in question and correspond, respectively, to the Latin "ens" and "essentia," English "being" and "essence," French "être" and "essence," Italian "essere" and "essenza," intended as "living being" on the one hand, and "essence of things," "that which is essential" as opposed to incidental, on the other. These languages then do not dispose of a single and ambiguous term corresponding to the German "Wesen," though this word does have an equivalent for polysemantism and plurivocality in the Russian "sochtchestwo," and in the Polish "istota." Consequently, as opposed to such languages as Russian and Polish which contain just an equivalent to the German "Wesen," as ambiguous as in French, English or Italian translations, a decision must be made: the meaning of the word "Wesen" must be decided each time it occurs in a given context, its sense determined for it to be appropriately rendered in the target language.

The situation gets even more complicated when we consider that two different and even contrasting official translations of the Theses are available in the French language: in fact the particular expression we are concerned with here, das menschliche Wesen, is rendered either as "l'essence humaine" (Euvres completes de Karl Marx, A. Costes, ed., 1937) or as "l'être humain" (Euvres choisies de Marx-Engels, Éditions du Progrès, Moscow, 1946). These different translations bear philosophical implications given that Marx is accordingly interpreted as 
discussing either the "essence of man" or the concrete "human being," the real human individual defined in his relations not only with nature but also with society of which, insofar as he is a social being, he is the product.

It should be observed that most official translations in various languages of Theses on Feuerbach derive from the original Russian translation. Strangely enough, the Russian translator Plechanov, in 1892, chose to render the German "Wesen" by the unambiguous Russian word "suschtschnost" (that is, "essence," "Wesenheit"), rather than by "suschtschestwo" which, similarly to the Polish "istota," has multiple meanings and is consequently closer to the German original. Having made this particular lexical choice, the Russian translator - a renowned authority, observes Schaff - was in fact to condition this text's future philosophical and political interpretations.

In French, as in Italian and English, the same word cannot be used indifferently as in the case of "Wesen," "istota," "suschtschestwo," and under the influence of the original Russian translation, "Wesen" is translated prevalently with the equivalents of "essentia," a solution which Schaff refuses in favour of the equivalents of "ens." He makes his decision by combining the results of a grammatical analysis with analysis of the philosophical context. In the face of such an ambiguous word as "Wesen," Schaff avers that the sense in which it is intended may be solved by appealing to the rules of German syntax.

If the expression "das Wesen" is followed by a noun in the genitive, it means "essence." Therefore, "das Wesen des Christentums," which is also the title of a work by Feuerbach, means "the essence of Christianity," and correspondingly "das Wesen des Religion" means "the essence of religion," "das Wesen des Menschen," "the essence of man." "Wesen" followed by "of something" or "of somebody" functions in the sense of "essence." On the other hand, if "Wesen" is preceded by a qualifying adjective, it means "being." Therefore, "das christliche Wesen" means "the christian being," "das religiöse Wesen" means "the religious being," "das menschliche Wesen," "the human being." In all these cases, as the syntax tells us, we are dealing with a "being" that is respectively Christian, religious, human. 
In the light of the connection not only between "sign" and "ideology," but above all between "sense" and "ideology," it would seem that for a semiotic approach to translation the problem of ideology must also be taken into account. The task of translation can only be properly accomplished if the translator is able to grasp and express the "sense" of a text: to remain at the level of the mere understanding of its "meaning" is not sufficient. Given that sense, as seen above, is no less than the evaluational orientation, standpoint, and expression to varying degrees of social planning, it is connected with ideology. Consequently what emerges is not so much the ideological character of translation as the inevitability of taking into account the problem of sense and therefore of ideology in translation theory (which I believe must necessarily be a semiotics of translation).

It is in this perspective that I have referred to the work of such thinkers as Sapir and Whorf: their theory of linguistic relativity implies a specific theory of translation and a specific ideological conception which obviously influenced, indeed, is at the basis of their rather limited vision of the very possibility of translation. It should also be mentioned that the theory of linguistic relativity hides an ideology of an ethnic-cultural order, an ideological orientation turned to justifying the various real forms of separation and segregation with respect to populations that speak languages different from our own, for the case in point, the Ameridian, to which studies conducted by Sapir and Whorf directly refer (cf. Solimini, 1974, pp. 98-102; 1991, pp. 30-33). On the other hand, the discussion concerning Marx's Theses on Feuerbach also stresses how the problem of translation is at the same time the problem of the correct interpretation of the ideology expressed in a text and, therefore, the problem of the ideological stance that the interpreter-translator must choose to take towards the text. Consideration of this issue as well helps shed light upon the close relation between ideology theory and translation theory viewed semiotically. Expressed differently, my focus throughout this study on the relation between semiotics, ideology and translation theory is motivated by the fact that, for an adequate treatment of the problem of translation, we must necessarily deal with the problem of the relation between "signification" and "significance," or "semantics" and "pragmatics," or if we prefer, between "meaning" and "ideological sense."

University of Bari, Italy 


\section{References}

BAKHTIN, Mikhail (1981). The Dialogic Imagination. Four Essays by M. M. Bakhtin. M. Holquist, ed. C. Emerson and M. Holquist, trans. Austin and London, University of Texas.

(1984a). Problems of Dostoevsky's Poetics. (Russian original 1963). C. Emerson, ed. and trans. Minneapolis, University of Minnesota Press.

(1984b). Rabelais and His World. (Russian original 1965). H. Iswolsky, trans. Bloomington, Indiana University Press.

(1986). Speech Genres and Other Late Essays. C. Emerson and M. Holquist, eds. V. McGee, trans. Austin and London, University of Texas Press.

(1990). Art and Answerabilty. Early Philosophical Essays by M. M. Bakhtin. M. Holquist and V. Liapunov, eds. Austin, Univeristy of Texas Press.

BAKHTIN, Mikhail and Valentin N. Volosinov (1973). Marxism and the Philosophy of Language. (Russian original 1929). L. Matejka and I.R.Titunik, trans. New York and London, Seminar Press; Cambridge, Harvard University Press, 1986.

(1987[1976]). Freudianism. A Critical Sketch. (Russian original 1927). I. R.Titunik, trans. I. R. Titunik and N. H. Bruss, eds. Bloomington and Indianapolis, Indiana University Press.

HARDWICK, Charles, ed. (1977). Semiotic and Significs. The Correspondence Between Charles S. Peirce and Victoria Lady Welby. Bloomington, Indiana University Press.

JAKOBSON, Roman (1971[1959]). "On Linguistic Aspects of Translation," in R. Jakobson, Selected Writings, vol. II. The Hague, Mouton, pp. 260-266. 
KRYSINSKI, Wladimir (1984). "Bakhtine et la question de l'idéologie," Études Françaises 20, pp. 21-36.

LÉVINAS, Emmanuel (1989[1968]). "Substitution," in E. Lévinas, The Lévinas Reader. S. Hand, ed. Oxford, Basil Blackwell, pp. 88-125.

MARX, Karl (1988). Selected Writings in Sociology and Social Philosophy. T. Bottomore and M. Rubel, eds. London, Penguin Books.

MORRIS, Charles (1964). Signification and Significance. A Study in the Relations of Signs and Values. Cambridge (Mass.), MIT Press.

PEIRCE, Charles S. (1931-58). Collected Papers. Cambridge (Mass.), The Belknap Press of Harvard University Press.

(1956). Chance, Love and Logic. N. Abbagnano, ed.; Caso, amore e logica. N. and M. Abbagnano, trans. Turin, Taylor.

PETRILLI, Susan, ed. and intro. (1985). V. Welby, Significato, metafora, interpretazione. Bari, Adriatica.

, ed and intro. (1987). Per Ferruccio Rossi-Landi. Il Protagora, XXVII(11/12). (Includes contributions from U. Eco, S. Petrilli, A. Ponzio, R. Posner, T.A. Sebeok, T. Slama-Cazacu).

(1988). Significs, semiotica, significazione. Bari, Adriatica.

(1990a). "The Problem of Signifying in Welby, Peirce, Vailati, Bakhtin," in Ponzio (1990a), pp. 315-363.

(1990b). "On the Materiality of Signs," in Ponzio (1990a), pp. 365-392.

(1990c). "Senso e analogia nel metalinguaggio di Victoria Welby," Idee, 13-15, pp. 71-78. 
(1990d). "Dialogue and Chronotopic Otherness: Bakhtin and Welby". Discours social/Social Disourse, III(1/2), pp. 339-350.

, intro. and ed. F. Rossi-Landi, Between Signs and Non-signs. Amsterdam, John Benjamins, forthcoming.

PONZIO, Augusto (1973). Produzione linguistica e ideologia sociale. Bari, Dedalo; revised and enlarged French edition, Production linguistique et idéologie sociale. Montréal, Éditions Balzac, forthcoming.

, ed., trans. and intro. (1975). A. Schaff and L.Sève, Marxism e umanesimo. Dedalo, Bari.

(1977). Marxismo, scienza e problema dell' uomo. Verona, Bertani.

(1981), "Polisemia e traduzione," in A. Ponzio, Segni e contraddizioni. Fra Marx e Bachtin. Bertani, Verona, pp. $15-42$.

Adriatica.

(1988). Rossi-Landi e la filosofia del linguaggio. Bari, (1990a). Man as a Sign. S. Petrilli, ed., trans. and intro. Berlin, Mouton.

(1990b). "Signs to Talk About Signs," in Ponzio (1990), pp. 15-74. (1990c). "Methodics of Common Speech in Rossi-Landi," in Ponzio (1990b), pp. 121-149.

(1991). "Segno e raffigurazione in Wittgenstein," in Ponzio, Filosofia del linguaggio 2. Bari, Adriatica, pp. 185-201. 
(1992). Fra semiotica e letteratura. Introduzione a Michail Bachtin. Milan, Bompiani.

[1992]. Signs, Dialogue, Ideology. S. Petrilli, ed. and trans. Amsterdam, John Benjamins, forthcoming.

ROSSI-LANDI, Ferruccio (1961[1980]). Significato, comunicazione $e$ parlare comune. Padua, Marsilio.

(1968). Il linguaggio come lavoro e come mercato. Milan, Bompiani; Language as Work and Trade. M. Adams, et al., trans. South Hadley (Mass.), Bergin and Garvey, 1983.

Mouton.

(1973). Ideologies of Linguistic Relativity. The Hague, (1982). Ideologia. Milan, Mondadori; Marxism and Ideology. R. Griffin, trans. Oxford, Clarendon, 1990.

(1985). Metodica filosofica e scienza dei segni. Milan, Bompiani.

SAUSSURE, Ferdinand de (1916). Cours de linguistique générale. Paris, Payot, 1964.

SEBEOK, Thomas A. (1981). The Play of Musement. Bloomington, Indiana University Press.

SOLIMINI, Maria (1974). "Antropologia, storia, etnolinguistica," in Scienza della cultura e logica di classe. Bari, Dedalo, pp. 61-103.

(1991). "Introduzione," in M. Solimini, ed., I diritti delle differenze. Sul sistema dell' apartheid. Bari, Edizioni dal Sud, pp. 11-33.

STEINER, George (1975). After Babel. Aspects of Language and Translation. London, Oxford University Press. 
WELBY, Victoria (1902). "Translation," in Dictionary of Philosophy and Psychology of Language in Three Volumes. J. M. Baldwin, ed. London, Macmillan.

(1983[1903]). What is Meaning? A. Eschbach, ed. Amsterdam, John Benjamins.

(1985[1911]). Significs and Language. H. W. Schmitz, ed. Amsterdam, John Benjamins.

WITTGENSTEIN, Ludwig (1961). Tractatus Logico-Philosophicus (German original 1921). D. F. Pears and B. F. Guiness, trans. B. Russell, intro. London, Routledge.

(1953). Philosophical Investigations (German original 1953). G. E. M. Anscombe, trans. Oxford, Blackwell. 